\title{
Comparison of calling songs in three allopatric populations of Endecous itatibensis (Orthoptera, Phalangopsinae)
}

\author{
Edison Zefa
}

Departamento de Zoologia e Genética, Universidade Federal de Pelotas, Campus Universitário s/n, 96010-900 Capão do Leão, RS. (edzefa@zipmail.com.br)

\begin{abstract}
Three isolated populations of the cricket Endecous itatibensis Rehn, 1918 had been analyzed to test the hypothesis of divergence in the calling song estridulation and to discuss its implications in the speciation process. The song registers were obtained from specimens in Corumbataí, Piraciacaba and Itatiba cities, state of São Paulo, Brazil. In the three analyzed populations, calling songs are composed by pairs of notes. Specimens from Corumbataí emit composed phrases with 3 to 18 pairs of notes, while those of Piracicaba and Itatiba have 1 to 3 pairs of notes. Inter- and intrapopulational variability in the frequencies of acoustic signals were detected. While recording the calling songs, other stridulations were registered, possibly from species of Orthoptera or Hemiptera. When the tapes were analyzed in the laboratory, it was verified that there was no overlap among the species' calling songs, in such a way that each species had their particular band of frequencies, avoiding interespecific acoustic competition.
\end{abstract}

KEYWORDS. Cricket, bioacoustics, acoustic competition, stridulation, speciation.

RESUMO. Comparação do som de chamado de três populações alopátricas de Endecous itatibensis (Orthoptera, Phalangopsinae). Foram analisadas três populações alopátricas do grilo Endecous itatibensis Rehn, 1918 com o objetivo de testar a hipótese de que houve divergência na estridulação de chamado e discutir as implicações no processo de especiação. Os registros sonoros foram obtidos de espécimes observados nos municípios de Corumbataí, Piracicaba e Itatiba, São Paulo, Brasil. Nas três populações analisadas, os sons de chamado são compostos por pares de notas. Foram observadas variações no ritmo de emissão dos pares de notas: E. itatibensis de Corumbataí emitem frases com 3 a 18 pares de notas e E. itatibensis de Piracicaba e Itatiba, frases com 1 a 3 pares de notas. Verificaram-se variação inter- e intra-populacional na freqüência dos sinais acústicos. Durante as gravações dos sons produzidos no processo de estridulação de chamado, foram registrados simultaneamente os sinais acústicos de outros insetos, possivelmente Orthoptera e Hemiptera. Ao analisar as freqüências destes sons em laboratório, constatou-se que estas nunca se sobrepõem, estabelecendo uma faixa particular de freqüência para cada espécie, evitando uma possível competição acústica interespecífica.

PALAVRAS-CHAVE. Grilo, bioacústica, competição acústica, estridulação, especiação.

The long-legged crickets of the subfamily Phalangopsinae are common in the tropical regions. They are more easily observed at night, when they leave their shelters under logs, rocks or bark, to forage on organic detritus, mushrooms and even small living insects. Some species are permanent or occasionally cavernicolous, feeding on decomposing matter and bat guano (KevAN, 1982; ОтTE \& ALEXANDER, 1983). The taxonomic structure of this family has been frequently modified in their subdivisions and categories. At present, the group is considered as a subfamily (Отте et al., 2003) within the superfamily Grylloidea, subdivided into three subfamilies: Homeogryllinae, Phalangopsinae and Luzarinae, placing the genus Endecous within the last one.

The genus was erected by SAussure (1878) for the Brazilian species E. arachnopsis, denominating the collecting locality as "Sierra Gival" which probably means Serra Geral, a quite inexact information. Up to now, ten species of the genus have been described, five of them (E. arachnopsis Saussure, 1878, E. itatibensis Rehn, 1918, E. cavernicolus Costa-Lima, 1940, E. abbreviatus Piza, 1960 e E. betariensis Mello \& Pellegatti-Franco, 1998) with type localities within the Brazilian territory.

Males of the genus Endecous, as many other crickets, have well developed tegmens. During calling, tegmens are elevated and rubbed one against the other. During each closing movement a portion of the anal edge of the left tegmen (the scraper) scratches a toothed vein (the file or pars stridens) on the underside of the right tegmen, resulting in a pulse of sound (WALKER, 1962; Alexander, 1962a; Walker \& Carlysle, 1975). Acoustic communication is essential for the reproductive biology of crickets and several authors dealt with that subject (Alexander, 1960, 1962a; Huber et al., 1989; Bailey, 1991; OtTE, 1992; DesutTER-GrandCOLAS, 1995, 1997).

The reproductive behavior of $E$. itatibensis comprises the calling song, sexual recognition, courtship, copulation and aggressive songs. The calling song is emitted to attract females for mating, that may act as a reproductive isolation mechanism. For this reason, the calling song's structure has been used by several authors as a taxonomic character (AleXANDER, 1957, 1962b; WALKer, 1964; OtTe \& AleXANDER, 1983).

Increasing destruction of the native vegetation of Brazil, particularly in the more densely populated state of São Paulo, has been carried out in the last three hundred years. The native vegetation has been replaced by urban areas, pastures for cattle or crops. Consequently, the insect fauna, mainly the flightless species, has been subdivided into small isolated islands.

Comparative analysis of the song in those recently isolated populations may detect structural changes that could discharge future speciation processes. Under these perspectives this study characterizes the calling song of 
three geographically isolated populations of $E$. itatibensis, with the purpose of evaluating if there are evidences of changes in the structure of their calling song.

\section{MATERIAL AND METHODS}

The specimens here studied were analyzed in three different vegetation remnants: 1) Corumbataí, cerrado forest; 2) Piracicaba, semideciduous seasonal forest, in the "Escola Superior de Agricultura Luis de Queiroz - ESALQ"; 3) Itatiba, semideciduous seasonal forest, km 91, rodovia D. Pedro I, in the "Bird Paradise" park. All the three localities are located in the state of São Paulo, Brazil.

The calling song of sixteen crickets was analyzed, six from Corumbataí (01.24.1996, 03.21.1996 and 04.24.1996), four from Piracicaba (11.08.1997 and 11.17.1998) and six from Itatiba (12.08.1998). The acoustic signals were registered in the field with a Nagra E tape recorder and a Sennheiser ME80 microphone. The sonograms were produced using Avisoft Light Version. Two song frequency variables were measured: the maximum (FMX) and the minimum (FMN) frequencies.

In order to analyze the acoustic signals, a nomenclature to describe the sonograms was modified from SAMwaYs (1976): each tooth of the pars stridens stimulates the emission of a sonorous pulse. A cluster of these pulses emitted during a movement of closing the tegmens forms a note (phonatome, according to LEROY, 1979). The phrases are formed by a group of notes emitted during an uninterrupted process of opening and closing the tegmens and the composed phrases are formed by a specific group of phrases (Fig. 1).

\section{RESULTS}

The specimens were found in nocturnal activity, most of them from October to May, stridulating on trunk surfaces with the forewings lifted approximately $90^{\circ}$ in relation to abdomen. In some cases, they were observed under leaves or small interweaved trunk branches near the trunk surface and between one to three meters above the ground.

Intrapopulational variation of FMX and FMN values of the acoustic signals was detected in specimens of Corumbataí and Piracicaba (Tab. I). These variations were not observed among the Itatiba specimens.

In all the specimens analyzed, the calling songs consisted of pairs of notes. Each pair of notes corresponds to a phrase, and they were emitted in groups designated "composed phrases"(Figs. 1a, b).

The Corumbataí specimens emit composed phrases containing 3 to 18 pairs of notes (Fig. 1). The Itatiba and Piracicaba specimens emit composed phrases of 1 to 3 pairs of notes (Figs. 2, 3, respectively). In some frequencies emitted by the Itatiba specimens, the time elapsed between the emission of those pair of notes was too irregular to allow the distinction of the composed phrases (Fig. 2).

The simultaneous recording of acoustic signals emitted by different species of insects, including $E$. itatibensis, allowed the construction of sonograms that show the absence of overlapping frequencies of the acoustic signals (Fig. 4).

Table I. Physical properties of the calling song of the E. itatibenis from the Corumbataí, Piracicaba and Itatiba sites (FMX, maximum frequency; FMN, minimum frequency).

\begin{tabular}{|c|c|c|c|c|c|}
\hline Specimens & Date & Schedule & Temperatures $\left({ }^{\circ} \mathrm{C}\right)$ & FMX (Hz) & FMN $(\mathrm{Hz})$ \\
\hline Corumbataí & 01.24 .96 & $20: 15 \mathrm{~h}$ & 27 & 3320 & 2960 \\
\hline Corumbataí & 03.21 .96 & $21: 00 \mathrm{~h}$ & 28 & 3120 & 2800 \\
\hline Corumbataí & 03.21 .96 & $20: 30 \mathrm{~h}$ & 28 & 3280 & 2880 \\
\hline Corumbataí & 03.21 .96 & $22: 00 \mathrm{~h}$ & 28 & 3600 & 3120 \\
\hline Corumbataí & 04.24 .96 & $20: 15 \mathrm{~h}$ & 26 & 3200 & 2800 \\
\hline Corumbataí & 04.24 .96 & $21: 00 \mathrm{~h}$ & 26 & 3360 & 2880 \\
\hline Piracicaba & 11.08 .97 & $21: 30 \mathrm{~h}$ & 28 & 3760 & 3280 \\
\hline Piracicaba $(n=3)$ & 11.17 .98 & $21-22 h$ & 26 & 3520 & 2960 \\
\hline Itatiba $(n=6)$ & 12.08 .98 & $20-22 h$ & 26 & 3120 & 2640 \\
\hline
\end{tabular}

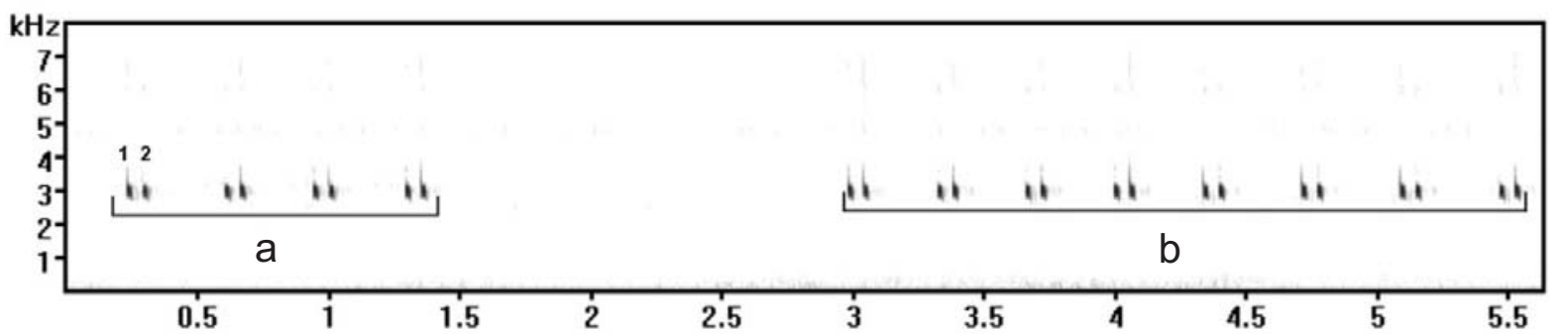

Fig. 1. Sonogram of the calling song of E. itatibensis from Corumbataí. 1, first note; 2, second note; $1+2$, phrase; a, composed phrase with four pairs of notes; $b$, composed phrase with eight pairs of notes. 

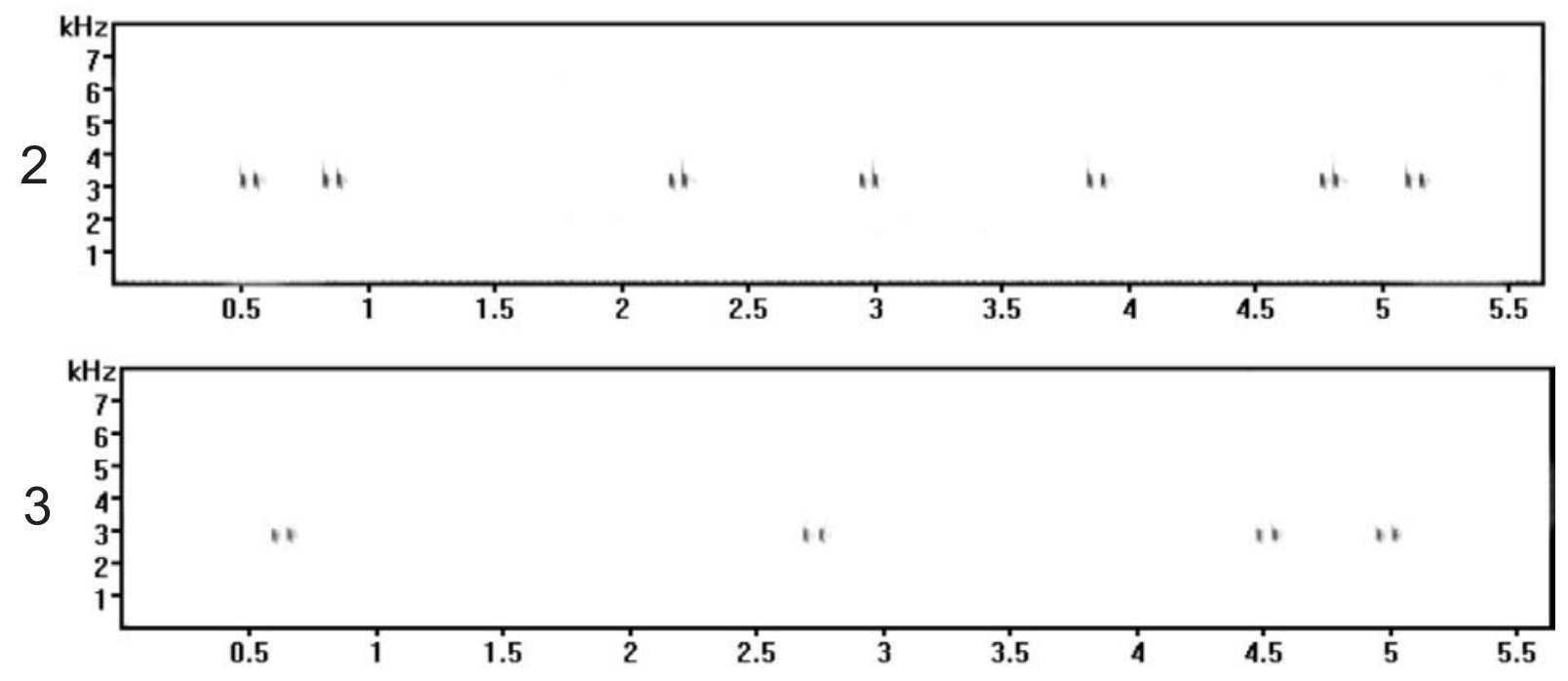

Figs. 2, 3. Sonogram of the calling song of E. itatibensis from: 2, Itatiba; 3, Piracicaba.

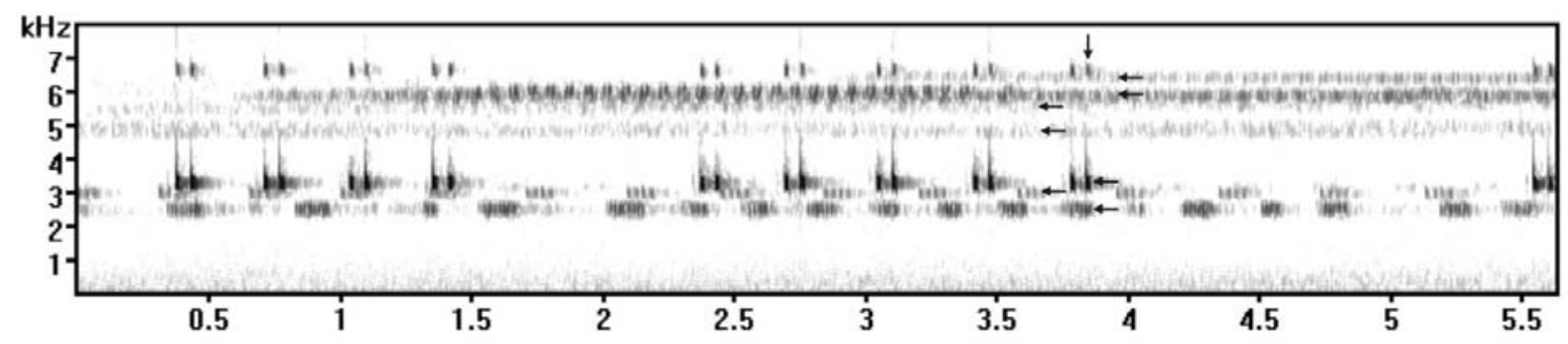

Fig. 4. Calling songs of several species, most probably belonging to Orthoptera and Hemiptera. Horizontal arrows indicate seven different calling songs; the third horizontal arrow (upwards) indicates the calling song of E. itatibensis and the vertical arrow points to E. itatibensis harmonic. The harmonics are frequencies that represent entire multiples of the fundamental frequency.

\section{DISCUSSION}

Populations of a single species living in different habitats as cerrado vegetation and densely forested area, may be selected for changes in the signaling songs, best adapted to the different ecological conditions. Changes in the acoustic repertoire are frequently followed by behavioral changes and both may contribute to a partial or complete isolation between formerly uniform populations, in such a way that an speciation process may be verified when those populations are assembled again in the same area. Such a speciation process may be occurring in some cryptic species of the genus Gryllus, living in the same habitat, at the same time of the year, up to three different specific songs are emitted by three cryptic species, including different rhythms and frequencies.

The grasshopper species Chorthippus brunneus (Thunberg, 1815) and C. biguttulus (Linnaeus, 1758), from England, are another example of speciation due to differences in song pattern. These grasshoppers are only distinguished by few morphological characters but both species emit different songs, although they present no further ecological distinction. Surprisingly, laboratory experimental crosses between these grasshopper species were possible (PERDECK, 1958) with production of viable offspring, although crosses were observed only rarely in natural conditions. Careful field studies revealed that the major difference between the species lays in the degree of stimulating and orienting influence of their songs (Matthews \& MATTHEws, 1978).

An intraspecific variation in the frequency and rhythm of the emitted signals might be common within Orthoptera. From an evolutionary point of view, this fact assures a variability of important signals that can be submitted to selective pressure to new environmental conditions, particularly those that occur when there are many species stridulating in the same period.

The differences in calling frequency among $E$. itatibensis and the other singing species are an evidence for an avoidance of a local interspecific acoustic competition. On the other hand, Matthews \& Matthews (1978) showed that some species of cricket have a span of hearing sensibility limited to the frequency of songs emitted by that species in particular. According those authors, if other species of crickets had the ear organs adjusted to a limited span, the songs emitted by other species would be almost inaudible. Then rhythm pattern of each could evolve without reference one to another, and songs could be rhythmically quite similar without leading to confusion (Fig. 4). If the rhythm is indeed an evolutionary independent character, different patterns of rhythm should be expected in the three allopatric populations of E. itatibensis, as observed. 
Another important selective character is the efficiency of song propagation. In E. itatibensis, the presence of well developed tegmens including those structures that amplify the songs, as well as the position of the males while singing at some distance from the ground, are conditions that improve the propagation of the acoustic signals and avoid distortions originated by the contact with the soil surface.

The preference for the emission of trills (long uninterrupted phrases) or chirps (short repeated phrases) may be analyzed under the perspective of energy demand. According to Prestwich \& WAlker (1981), the emission of chirps consumes a smaller amount of energy. On the other hand, chirps can be less attractive to females than trills, as verified by HEDRICK (1986) in Gryllus integer Scudder, 1902.

The evolution of the rhythm pattern in calling songs was discussed by Alexander (1960), who argues that the trills represent the most common kind of calling song within Orthoptera, being the chirps the following step in the evolution of acoustic signal emission.

The evolutionary source of chirps allowed the development of a great quantity of distinct calling songs, because different species could stridulate a variety of song assemblages in different time intervals. Отте (1992) clearly defined a great variability in the main rhythm found in the acoustic communication of crickets.

Comparing the rhythm of emission in compound phrases emitted by E. itatibensis in the Corumbataí population, in relation to those of Piracicaba and Itatiba, it was verified that "dialects" can be established among species geographically isolated.

Experiments testing the phonotaxis and intercrosses between specimens of these populations could contribute to define those variations as being inter- or intraspecific. A similarity in the structure of tegmen, phallic complex and karyotype previously analyzed suggests that the geographical isolation among these populations is recent and that the different habitats possibly are selecting distinct acoustic signals.

Acknowledgments. I would like to thank Prof. Dr. Alejo Mesa (UNESP) for the suggestions and encouragement. To Ana Paula Z. Silva (FAM), Fábio Passetti (USP), Mara C. de Almeida (UEPG), Akio R. Miyoshe (UNESP), Rogilene Ap. Prado (UNESP) for their help in field work. To Cristiane Meleo for helping in the graphical part of the sonograms. Research supported by CNPq, process 141738/95-2.

\section{REFERENCES}

Alexander, R. D. 1957. The taxonomy of the field crickets of the Eastern United States (Orthoptera: Gryllidae: Acheta).
Annals of the Entomological Society of America 50(6):584-602.

1960. Sound communication in Orthoptera and Cicadidae. In: Lanyon, W. E. \& Tavolga, W. N. eds. Animal sounds and communication. Washington, American Institute of Biological Science. p.38-92 (Publication, 7).

1962a. Evolutionary change in cricket acoustical communication. Evolution 16(4):443-67.

. 1962b. The role of behavioral study in cricket classification. Systematic Zoology 11(2):53-71.

Bailey, W. J. 1991. Acoustic behavior of insects. Cambridge, Cambrige University. 225p.

Desutter-Grandcolas, L. 1995. Toward the knowledge of the evolutionary biology of phalangopsid crickets (Orthoptera: Grylloidea: Phalangopsidae): data, questions and evolutionary scenarios. Journal of Orthoptera Research 4:163-75.

1997. Acoustic communication in crickets (Orthoptera: Grylloidea): a model of regressive evolution revised using phylogeny. In: Grandcolas, P. P. ed. The origin of biodiversity in insects: phylogenetic tests of evolutionary scenarios. Paris, Mémoires du Muséum National d'Histoire Naturelle. v.173, p.183-202.

Hedrick, A. V. 1986. Female preferences for male calling bout duration in field cricket Gryllus integer. Behavioral Ecology and Sociobiology 19:73-77.

Huber, F.; Moore, T. E. \& Loher, W. 1989. Cricket behavior and neurobiology. London, Cornell University. 565p.

Kevan, D. K., McE. 1982. Orthoptera. In: Parker, S. P. ed. Synopsis and classification of living organisms. New York, McGraw-Hill. p.379-382.

Leroy, Y. 1979. L'univers sonore animal. Paris, GauthierVillars. 350p.

Matthews, R. W. \& Matthews, J. R. 1978. Insect behavior. New York, John Wiley \& Sons. 507p.

Отте, D. 1992. Evolution of cricket songs. Journal of Orthoptera Research 1:25-49.

Otte, D. \& Alexander, R. D. 1983. The Australian crickets (Orthoptera: Gryllidae). Monographs of the Academy of Natural Sciences of Philadelphia 22:1-477.

Otte, D.; Eades, D. C. \& Naskrecki, P. 2003. Orthoptera species file online (version 2). Available at: <http:// osf2.orthoptera.org/basic/HomePage.asp>. Access in: 25.11.2003.

Perdeck, A. C. 1958. The isolating value of specific song patterns in two sibling species of grasshoppers (Chorthippus brunneus Thunb. and C. biguttulus L.). Behaviour 12:175.

Prestwich, N. K. \& Walker, T. J. 1981. Energetics of singing in crickets: effect of temperature in three trilling species (Orthoptera: Gryllidae). Journal of Comparative Physiology 143:199-212.

SAMwAYS, M. J. 1976. Song modification in the Orthoptera. I. Proclamation songs of Platycleis spp. (Tettigoniidae). Physiological Entomology 1:131-49.

Saussure, H. 1878. Mélanges Orthoptèrólogiques. Fascicule 6. Gryllides 2. Genève, H. Georg. p.506-837.

Walker, T. J. 1962. Factors responsible for intraspecific variation in the calling songs of crickets. Evolution 16(4): 407-28.

1964. Cryptic species among sound-producing Ensiferan Orthoptera (Gryllidae and Tettigoniidae). Quarterly Review of Biology 39:345-55.

Walker, T. J. \& CARlysle, T. C. 1975. Stridulatory file teeth in crickets: taxonomic and acoustic implications (Orthoptera: Gryllidae). Journal of Insect Morphology and Embriology 4(2):151-8.

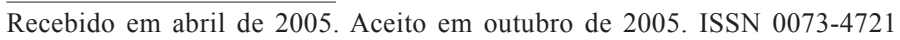

Artigo disponível em: www.scielo.br/isz 